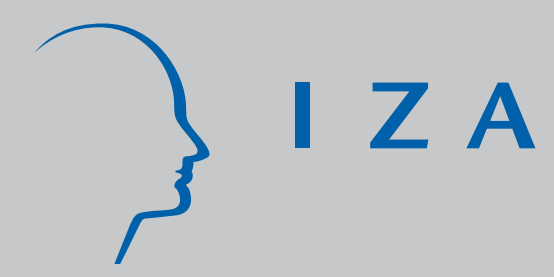

IZA DP No. 2203

Income Taxes and the Composition of Pay

Giorgio Brunello

Simona Comi

Daniela Sonedda

J uly 2006 


\title{
Income Taxes and the Composition of Pay
}

\author{
Giorgio Brunello \\ University of Padova, \\ CESifo and IZA Bonn \\ Simona Comi \\ University of Milano Bicocca \\ Daniela Sonedda \\ University of Piemonte Orientale \\ and CRENoS
}

\section{Discussion Paper No. 2203 \\ July 2006}

IZA

P.O. Box 7240

53072 Bonn

Germany

\author{
Phone: +49-228-3894-0 \\ Fax: +49-228-3894-180 \\ Email: iza@iza.org
}

\begin{abstract}
Any opinions expressed here are those of the author(s) and not those of the institute. Research disseminated by IZA may include views on policy, but the institute itself takes no institutional policy positions.
\end{abstract}

The Institute for the Study of Labor (IZA) in Bonn is a local and virtual international research center and a place of communication between science, politics and business. IZA is an independent nonprofit company supported by Deutsche Post World Net. The center is associated with the University of Bonn and offers a stimulating research environment through its research networks, research support, and visitors and doctoral programs. IZA engages in (i) original and internationally competitive research in all fields of labor economics, (ii) development of policy concepts, and (iii) dissemination of research results and concepts to the interested public.

IZA Discussion Papers often represent preliminary work and are circulated to encourage discussion. Citation of such a paper should account for its provisional character. A revised version may be available directly from the author. 
IZA Discussion Paper No. 2203

July 2006

\section{ABSTRACT}

\section{Income Taxes and the Composition of Pay*}

According to the standard principal-agent model, the optimal composition of pay should balance the provision of incentives with the individual demand for insurance. Do income taxes alter this balance? We show that the relative share of PRP on total pay is reduced by higher average taxes, and is affected in a complex way by higher marginal tax rates. Empirical evidence based on the British Household Panel Survey, which exploits the UK 1999 Tax Reform, supports the theoretical predictions of the tax-augmented principal-agent model.

JEL Classification: $\quad$ J33, H24

Keywords: performance related pay, income taxes

Corresponding author:

Giorgio Brunello

Department of Economics

University of Padova

Via del Santo 33

35100 Padova

E-mail: giorgio.brunello@unipd.it

\footnotetext{
* We are grateful to Erich Battistin and Lorenzo Cappellari for advice on the empirical part of this paper, and to Elena Bardasi for help on the micro-simulation of net monthly earnings in the BHPS dataset. The data used in this paper were made available by the ESRC Data Archive. The data were originally collected by the ESRC Research Centre on Micro-social Change at the University of Essex (now incorporated within the Institute for Social and Economic Research). Neither the original collectors of the data nor the Archive bear any responsibility for the analyses or interpretations presented here. The usual disclaimer applies.
} 


\section{Introduction}

Performance related pay (PRP) is often heralded as a tool which helps aligning the employee's incentives with those of the firm (See Lazear, 1999), and as a compensation device more suitable to the spreading information - intensive production technologies and new ways of organizing labour (see Freeman, 1999). Many believe that PRP has beneficial effects on worker commitment, work morale and productivity, and this belief is supported by empincal evidence - see for instance OECD, 1995, and Doucouliagos, 1995).

Standard principal agent theory shows that the appropriate level of pay-performance sensitivity should balance risk and incentives, and that this balance depends on the cost of effort, the degree of risk aversion of the parties and the distribution of shocks affecting individual and firm performance (see Prendergast, 1999). An additional factor affecting PRP which has been overlooked in the literature is the structure of income taxation. In this paper, we incorporate the tax structure, which we characterize with the average and the marginal tax rate, into the standard principal-agent model, and study how changes in the selected tax variables affect the optimal composition of pay ${ }^{1}$.

We believe that this is a useful extension, because of two broad trends characterizing many OECD economies. On the one hand, average personal taxes for average production workers have declined in most OECD countries from 1996 to 2004 (OECD, 2004). This decline has been accompanied by changes in the structure of the marginal tax rates, and in some countries by a consistent reduction in the top marginal tax. On the other hand, flexible compensation policies - with their emphasis on the relationship between performance and pay - are spreading in modem economies together with the diffusion of organizational changes and new information technologies. While there are several reasons behind these trends, a common denominator is the desire to improve economic efficiency. This paper suggests that a by-product of tax reforms which reduce average and marginal income taxes is the increase in the relative share of PRP on total pay.

Starting with Malcomson and Sartor, 1987, and Lockwood and Manning, 1993, the relevant literature has focused mainly on the relationship between taxation and pay, and on the implications of such relationship for the unemployment rate. One key result in this a rea is that, when labour supply is endogenous, the effect of tax progressivity on wages is

\footnotetext{
${ }^{1}$ As a rgued by Garen, 1994, a promising way of testing the implic ations of the principal-agent model is the method of comparative static s, which studies how PRP varies with changes in income taxation.
} 
ambiguous. Rather than following this literature and its emphasis on the implications of taxation for total pay, this paper focuses instead on the effects of taxation on the composition of pay.

We show that the relative share of performance related pay over total pay una mbiguously dec lines when average income taxes increase. We also show that the effect of an increase in marginal tax rates on the share of PRP is a mbiguous and cannot be signed a priori. We submit these theoretical results to empiric al scrutiny by using UK data. The United Kingdom is interesting in this area for two reasons: first, the UK govemment has actively encouraged the diffusion of PRP in the private sector ${ }^{2}$. As described for instance by Booth and Frank, 1999, since 1991 a substantial share of total pay in the UK was exempt from income taxes if received as PRP. The large increase in the percentage of employees receiving PRP led the govemment to phase out these tax breaks from 1997 onwards, and to abolish them starting from the year 2000. Second, the UK has experienced a significant tax reform in 1999, which has affected both marginal and average tax rates. We use the exogenous changes produced by this reform to identify the relationship between income taxation and PRP.

Our empirical investigation uses the data drawn from 7 waves (1997-2003) of the British Household Panel Survey (BHPS), a longitudinal representative survey of British households, which covers the years before and after the 1999 Tax Reform. Consistently with the theoretical predictions of the tax-augmented principal-agent model, we find that the share of PRP on total pay increases when the average tax rate decreases. We also find that lower marginal tax rates raise the relative importance of PRP. Importantly, the size of these effects is relatively large: our empirical estimates suggest that a 10 percent reduction in the marginal and average tax rates increase the share of PRP on total pay by 2.80 and 7.99 percent respectively.

The paper is organized as follows: the model of PRP and taxation is presented in the next section. The empirical strategy is disc ussed in Section 2, and the data are introduced in Section 3. Section 4 briefly illustrates the UK Tax Reform of 1999. The following section presents and disc usses the results. Conclusions follow.

\footnotetext{
2 There is a growing literature on the use of PRP in the public sector. In this paper, however, we focus only on the private sector.
} 


\section{The Theoretical Model}

The premise of agency theory is that a principal designs contracts to guide appropriate actions by an agent (Prendergast, 1999). Consider a static model, where the agent - the employee - is assumed to take some action (effort). A component $\mu_{o} \geq 0$ of this action is observed by both parties, but a component $\mu$ is not observed by the principal - the employer. The action affects the measure of performance $Y$ according to the relationship

$Y=\mu_{0}+\theta \mu+\varepsilon$

where $i$ is for the agent, $\theta$ is the productivity of the action $\mu$, and $\varepsilon$ is a random component, which impairs the inference of the action from the observation of output. We restrict our attention to linear compensation schemes of the sort

$W=a+b\left(Y-\mu_{o}\right)$

where $W$ is gross pay, $a$ is the fixed component which remunerates observable effort and $b$ is the "piece rate" on performance above the minimum level of observable effort. Employees are risk averse and care about their net pay $W-T(W)$, where $T$ is the tax function. Using the second orderapproximation of $\mathrm{T}$

$T(W)=T(a+b \theta \mu)+\tau b \varepsilon+\frac{\tau^{\prime}}{2} b^{2} \varepsilon^{2}$

where $\tau=T^{\prime}(W)$ is the (progressive) marginal tax rate and $\tau^{\prime}=T^{\prime \prime}(W)^{3}$, expected gross wages and taxes are respectively $E W=a+b \theta \mu$ and

$E T(W)=T(a+b \theta \mu)+\lambda b^{2} \sigma_{\varepsilon}^{2}$

where $\lambda=\frac{\tau^{\prime}}{2}$. Moreover, the variance of taxes is $\operatorname{Var}(T)=\tau^{2} b^{2} \sigma_{\varepsilon}^{2}$, where we ignore for the

30 ne prime for the first derivative and two primes for the second derivative. 
sake of simplic ity the moments of order higher than 2.

With these premises, the certa inty equivalent of the uncerta in income stream accruing to employee $i$ is

$$
C E_{w}=a+b \theta \mu-T(a+b \theta \mu)-\lambda b^{2} \sigma_{\varepsilon}^{2}-\phi \frac{\mu^{2}}{2}-\frac{1}{2} r b^{2} \sigma_{\varepsilon}^{2}\left(1+\tau^{2}\right)
$$

where $r$ is the absolute degree of risk aversion, $\sigma_{\varepsilon}^{2}$ is the variance of the noise, $\phi \frac{\mu^{2}}{2}$ is the cost of effort and $\frac{1}{2} r b^{2} \sigma_{\varepsilon}^{2}\left(1+\tau^{2}\right)$ is the risk premium 4 . Each employee chooses the optimal level of effort by maximizing hercerta inty equivalent income with respect to $\mu$, which yields

$$
\mu=\frac{b \theta(1-\tau)}{\phi}
$$

Effort above the minimum observable level is increasing in the piece rate and in the productivity of effort, and decreasing in the cost of effort and in the marginal tax rate.

Risk neutral employers ta ke into account both the incentive compatibility constraint (6) and the worker participation constraint

$$
C E_{w}=\bar{U}
$$

where $\bar{U}$ is the reservation level of income. In this environment, profit maximization is equivalent to the maximization of the sum of the employer's and employee's certainty equivalent incomes. The employer's certa inty equivalent is

$C E_{\pi}=\mu_{o}+\theta \mu-(a+b \theta \mu)$

and the sum of certa inty equivalents is

$C E=\mu_{o}+\theta \mu-T(a+b \theta \mu)-\lambda b^{2} \sigma_{\varepsilon}^{2}-\phi \frac{\mu^{2}}{2}-\frac{1}{2} r b^{2} \sigma_{\varepsilon}^{2}\left(1+\tau^{2}\right)$ 
Using (6) and (7) into (9), the maximization of $C E$ with respect to the piece rate $b$ yields

$$
b=\frac{1}{1+\tau+\frac{2 \lambda \phi \sigma_{\varepsilon}^{2}}{\theta^{2}(1-\tau)}+\frac{r \sigma_{\varepsilon}^{2}\left(1+\tau^{2}\right) \phi}{\theta^{2}(1-\tau)}}
$$

If the parameter $\lambda$ is small enough to be safely ignored, the above expression simp lifies into

$$
b=\frac{1}{1+\tau+\frac{r \sigma_{\varepsilon}^{2}\left(1+\tau^{2}\right) \phi}{\theta^{2}(1-\tau)}}
$$

The optimal piece rate has the usual properties: it is higher for individuals with lower risk aversion and lower for individuals with low productivity $\theta$ and high cost of effort $\phi$. The variance of the noise $\sigma_{\varepsilon}^{2}$ also affects negatively the piece rate (see Garen, 1994).

Notice that only extreme and unrealistic values of progressive taxation $(\tau=1)$ can yield a zero piece rate $b$. Variations of $\tau$ within a more realistic range affect the size of the piece rate but do not determine whether the employer will or will not pay performance related pay. This willingness instead depends on the productivity and cost of effort, the degree of risk aversion, and the variance of unobserved noise.

Since the employer can tailor the optimal piece rate to the characteristics of the employee and the job, the sorting which occurs in this simple model is regulated by the participation constraint: only individuals who receive at least their reservation utility accept the piece rate designed by the employer ${ }^{5}$. Let the reservation income be equal to income from unemployment $\rho$. Then $\bar{U}=(1-z) \rho$, where $z$ is the average tax rate, and the fixed component of pay, $a$, is given by 6

\footnotetext{
5 Booth and Frank, 1999, propose a sorting mechanism for performance related pay. 6Here we assume that the average tax rate on unemployment benefits is the same applied to average pay.
} 
$(a+b \theta \mu)(1-z)-\frac{\phi \mu^{2}}{2}-\frac{1}{2} r b^{2} \sigma_{e}^{2}=(1-z) \rho$

If the employee has no bargaining power in her match with the employer, the above condition holds as equality. Let $\beta$ measure the relative bargaining power of the employee, who can bargain with the employer for a higher certainty equivalent income. Then the above condition becomes

$(a+b \theta \mu)(1-z)=(1+\beta)(1-z) \rho+\frac{\phi \mu^{2}}{2}+\frac{1}{2} r b^{2} \sigma_{e}^{2}$

With this structure in hand, we ask whether the structure of taxation affects the composition of gross pay into the fixed and performance related components. Define $R$ as the ratio of (expected) gross perfomance related pay to (expected) gross total pay. This ratio increases when the ratio of fixed to variable pay falls. We can show that $R$ is equal to

$$
R=\frac{b \theta \mu}{a+b \theta \mu}=\frac{2 \theta^{2}}{\left[v \theta^{2}+\frac{\phi v r \sigma_{e}^{2}}{(1-\tau)^{2}}+\frac{2 \phi(1+\beta) \rho}{b^{2}(1-\tau)}\right]}
$$

where $v$ denotes the coefficient of residual income progression $v=\frac{1-\tau}{1-z}$. Differentiation with respect to $z$ and $v$ yields

Result The relative share of PRP on total pay declines when average taxation increases. The effect of an increase in progressive taxation on the ratio cannot be signed a priori.

\section{Proof: See Appendix}

The first part of the result depends on the fact that (expected) PRP does not depend on the average tax rate. To see this, re-write expected PRP as

$b \theta \mu=\frac{b^{2} \theta^{2}(1-\tau)}{\phi}$ 
and notice that the piece rate $b$ depends only on the marginal tax rate. On the other hand, total pay needs to increase with the average tax rate for the participation constraint to be satisfied. The second part of the result hinges on the fact that both PRP and total pay are reduced when marginal tax rates increase.

\section{The Empirical Strategy}

A clear empirical implication of the standard principal - agent model is that an increase in the average tax pressure reduces the ratio between the variable and the fixed components of pay. In the rest of the paper, we submit this prediction to empirical investigation. On the other hand, since the relationship between marginal tax rates and the composition of pay is ambiguous, we have no precise hypothesis for testing, and we use the empiric al a nalysis to resolve this a mbiguity.

In the empincal implementation, we use a log-linear approximation of (14). Since $R$ can be either zero or take continuous positive values, we define the following Tobit model

$$
\begin{aligned}
& \ln \left(1+R_{i t}^{*}\right)=x_{i t}^{\prime} \gamma_{1}+y_{t}^{\prime} \gamma_{2}+\gamma_{3} \ln (1-\tau)_{i t}+\gamma_{4} \ln (1-z)_{i t}+v_{i}+\xi_{i t} \\
& \ln \left(1+R_{i t}\right)=0 \text { if } R_{i t}^{*} \leq 0 \\
& R_{i t}=R_{i t}^{*} \text { if } R_{i t}^{*}>0
\end{aligned}
$$

where $R^{*}$ is the latent variable, $x_{i t}$ and $y_{i t}$ are vectors of individual and aggregate controls, $i$ is for the individual, $t$ for time, and we decompose the nomally distributed error term into a time invariant ind ividual effect $v$ and additional noise $\xi$.

The theoretical model suggests that the composition of pay depends on the cost of effort $\varphi$, the index of risk aversion $r$, the productivity of effort $\theta$, the variance of the noise $\sigma_{\varepsilon}{ }^{2}$, income from unemployment $\rho$ and the relative bargaining power of the worker $\beta$. We proxy the individual cost of effort with age, age squared, marital status, gender, educational dummies, and measures of individual health, which include a dummy for the lack of sleep and a dummy for the recent use of medic al facilities; risk aversion is proxied by indic ators of smoking attitudes, the participation to lotteries and race; the productivity of effort and the variance of shocks are captured by industry, size, regional and occupational dummies, and by measures of previous job history; the relative bargaining power of the individual is 
captured by indicators of the presence of a union in the workplace and by political preferences; finally, income from unemployment is proxied by the national unemployment rate.

The macroeconomic effects on the composition of pay are captured in a parsimonious way with a linear, a quadratic trend and the national unemployment rate. British govemment policy introduced tax breaks during the 1990s, with the aim of encouraging the diffusion of profit related pay. These breaks were phased out in the late 1990s, and completely eliminated from 2000 onwards. We account for this policy with a dummy equal to 1 for the years 2000 - 2003 (no breaks) and to 0 for the previous years (19971999).

Even after conditioning for the set of individual and aggregate controls, the relationship between the composition of pay and the two tax instruments can be plagued by two main factors: a) there are unobserved individual and time invariant characteristics, such as the component of individual ability which is not captured by education and job allocation, or the individual cost of effort, which are likely to affect both PRP and the tax rates; b) there could be reverse causality, running from the composition of pay to the tax instruments. Reverse causality can occur, for instance, if shocks to gross pay affect by construction both the index of tax progressivity and the income tax retention rate $(1-z)$. As disc ussed by Gruber, 1995, measurement errors in the annual wage can generate a spurious correlation between the gross pay, the average and the marginal tax rate. In particular, positive innovations to the measurement error raise the measured annual wage and reduce the average tax rate. The presence of reverse causality implies that the tax variables in model (16) can be endogenous even after controlling for time invariant individual effects.

We deal with the potential correlation of the tax variables with the unobserved individual effects by replacing the former in the first equation of model (16) with their deviations from the individual means. As shown by Altonji and Shatotko, 1987, this transfomation implies that the new tax variables are orthogonal by construction to the time invariant individual effect 7 .

We address the endogeneity of the tax variables, which is induced by reverse causality, with the methodology suggested by Smith and Blundell, 1986. For each tax variable, we nun an auxiliary regression which includes among the regressors all the

\footnotetext{
7 In practice, the first equation in (16) is replaced by $\ln \left(1+R_{i t}^{*}\right)=x_{i t}^{\prime} \gamma_{1}+y_{t} \gamma_{2}+\gamma_{3}\left[\ln (1-\tau)_{i t}-\overline{\ln (1-\tau)_{i t}}\right]+\gamma_{4}\left[\ln (1-z)_{i t}-\overline{\ln (1-z)_{i t}}\right]+\left[v_{i}+\gamma_{3} \overline{\ln (1-\tau)_{i t}}+\gamma_{4} \overline{\ln (1-z)_{i t}}\right]+\xi_{i t}$ where the upperbar is for the individual means. One implication of this transformation is that the time invariant component of the errorterm now includes the ind ividual means.
} 
exogenous variables plus the selected instruments. Next, we take the residuals from these regressions and add them to the list of explanatory variables in each Tobit model. This methodology ensures that the estimates of the key parameters $\gamma_{3}$ and $\gamma_{4}$ are consistent, and also allows us to test the weak exogeneity of the tax variables using simple Tand F tests8.

\section{The Data}

The data set used in this paper is drawn from the seven waves (from 1997 to 2003) of the British Household Panel Survey (BHPS). The BHPS is a nationally representative household survey conducted annually since 1991 on more than 5000 British households, or about 10000 individuals a year. The survey includes information on gross pay and on household and job characteristics, which we use to compute both net pay ${ }^{9}$ and individual average and marginal tax rates. Since 1997 (wave 7), interviewed individuals a re asked whether their pay include a bonus, the amount of the bonus and whether this a mount is gross or net. The key question is

"In the last 12 months have you received any bonuses such as a Christmas or quarterly bonus, profit-related pay or profit sharing bonus, or an occasional commission? “

Overtime pay is explicitly excluded. Those who have received performance related pay are then asked the total a mount received, and whether this a mount was before or after tax. We select the sub-sample of employees in the private sector, who report positive gross ea mings and provide information on all the relevant variables used in the empirical analysis. We restrict further by selecting the individuals aged between 17 and 65 in the case of males, and less than 60 in the case of females, and end up with a sample of 29731 individual-wave observations.

As shown in Table 1, the individuals in our sample in 2003 have an average age close to 38 years, more than half of them are mamed and about $56 \%$ are males; $16 \%$ of them work part-time, $96 \%$ have a pemanent job and one close to 20 percent have a union in the workplace. Only a small minority (7 percent) had a father unemployed at the age of 14 ,

\footnotetext{
8Under the null of weak exogeneity the variance covariance matrix of the estimates is equivalent to the standard tobit variance covariance matrix. See Wooldridge, 2002. 9Following Bardasi and J enkins, 2004, we compute ind ividual net pay starting from gross monthly eamings. An appendix expla ining the computation procedure is available upon request from the authors.
} 
about one third consists of smokers and about one fourth voted for the Labour party in the last election. When we restrict the sample to managers and professionals, we find the parttime and smoking rates are reduced, but the remaining characteristics are broadly unchanged.

The percentage of employees receiving PRP was 33.5 percent in 2003, down from 36.1 percent in 1997. These percentages are very close to those found in the Workplace Industrial Relations Survey (WERS), which reports 37.4 percent in 1998 (see Conyon and Freeman, 2001). Conditional on receiving PRP, the average share of PRP in the sample was 6.4 percent in 2003, down from 6.6 percent in 1997. On average, the marginal tax rate declined from 23.1 percent in 1997 to 22.3 percent in 2003, while the average tax rate increased from 11 percent in 1997 to 12 percent in $2003^{10}$.

[Table 1 about here]

\section{The Tax Reform and the abolition of tax breaks for PRP}

During the last decade, the UK taxation system has undergone a series of substantial reforms. The key changes for the purpose of this paper are the reduction in the starting marginal tax rate from 20 to 10 percent in 1999, the reduction of the basic marginal tax rate from 23 to 22 percent in 2000, and the introduction of the Working Family Tax Credit (WFTC) in 199911. The WFTC introduced in-work family benefits, with the goal of supporting low income families with children, while avoiding at the same time the reduction of labour supply. In this scheme, a household with a dependent child was entitled to receive tax credits if at least one of the parents worked 16 hours or more a week. The Working Fa mily Tax Credit consisted of a basic credit, which increased with the number of children and was more generous with people working more than 30 hours a week. An additional aspect was that up to the $70 \%$ of eligible childcare costs could be deducted from taxes ${ }^{12}$. Compared to the previous system of Family Credit (FC), which was mainly a benefit system not administered by the Inland Revenue, the WFTC benefited around 1,271 million households in 2001, compared to the 817 thousands reached by FC in 1999, and was more generous - see Lydon and Walker, 2004.

A substantial body of economic literature has investigated the effects of the tax reform on altemative outcomes, ranging from labour supply (see Francesconi and van der

\footnotetext{
${ }^{10}$ The construction of individual marginal and average tax rates is described in the Appendix, Section 2.

${ }^{11}$ The WFTC was replaced in 2004 by the WFC and CTC.

${ }^{12}$ The Working Family Tax Credit introduced also credits for disabled people, which are not relevant for our analysis.
} 
Kla auw,2004) to child poverty (see Brewer et al., 2003). According to these and other studies, the changes in the marginal tax rates taking place in 1999 and 2000 affected the entire income distribution, but the biggest gains were experienced by the households in the $2^{\text {nd }}$ poorest decile, who experienced a $5 \%$ increase in their net income.

In the late 1980s, the UK govemment has promoted with tax breaks the diffusion of perfomance related pay. The govemment's main goal was to combat wage "stickiness" and increase wage flexibility. In 1987, tax relief was given on half of PRP up to a limit of the lower of $£ 3000$ or $20 \%$ of the employee's pay. This ceiling was increased to $£ 4,000$ in 1989 . Tax relief was extended in 1991 to the whole of the PRP payment. In 1997, the govemment decided to phase out tax relief on PRP over a three to four year period. The ceiling on relief was reduced to $f 2000$ in 1998 and to $f 1000$ in 1999. No relief was available since 2000 onwards (see Conyon and Freeman, 2001).

\section{Results}

In our baseline specification, we use a parsimonious specification of the aggregate effects, replace the tax variables with the deviations from their individual means, and augment the set of independent variables with the residuals of the first stage regressions of the tax variables on the exogenous variables and the selected instruments.

Our instruments exploit the exogenous changes in the marginal tax rates and in the tax bands which took place over the time period. As described in the previous section, the starting marginal tax rate, TR1, was reduced from 20 to 10 percent in 1999. This change anticipated the smaller reduction in the basic marginal tax rate, $\mathbb{R} 2$, from 23 to 22 percent, which occurred in the year 2000. Since this second change coincided with the phasing out of the tax breaks offered by the govemment to encourage the diffusion of PRP, the discontinuity in the year 2000 cannot be used as an additional instrument. Therefore, we focus on the discontinuity produced by the change in the starting marginal tax rate.

While the changes in marginal tax rates have occurred only once during the sample period, tax bands have been changed every year. In particular, the lower income limit for the basic marginal tax rate was reduced drastically from 4300 to 1500 pounds in 1999, when the starting marginal tax rate was also reduced. We define the variable GAP2 as the difference between the upper and the lower limit of the basic marginal tax rate, which we deflate with the consumer price index over the sample period. It tums out that the tax band exhibits an abrupt increase in 1999, and increases mild ly in the remaining period.

We expect that the decrease in the lowest marginal tax rate TR1 and the variations in 
the tax band GAP2 affect both the average and the marginal tax rate of the individuals in the sample, and that this effect can vary across the population. We posit that different groups of individuals may react $d$ ifferently to the tax reform, either because they are touched differently or because of endogenous changes in the allocation of time and, consequently, in the resulting tax rates. We capture this variability in the impact of the tax reform by interacting the lowest marginal tax rate with a female dummy and the intermediate tax rate with a male dummy.

To motivate these interactions, consider for instance the intermediate marginal tax TR2. In the year 1999, before the tax was reduced from 0.23 to 0.22 , the percentage of males with this marginal tax was 84 percent, compared to only 56 percent for females. Therefore, we would expect males to be touched to a higher extent by the reform. Needless to say, the differential response by gender reflects also how males and females react to the reform in terms of their la bour supply and effort decisions. Similarly, the starting marginal tax rate before the reform which reduced it from 0.2 to 0.1 was concentrated mainly among females: close to 51 percent of females had this marginal tax rate in 1998, compared to only 10 percent of males.

Table 2 reports the estimates of the first stage regressions of the marginal and average tax rates on the exogenous variables and the selected instruments. While the former two columns refer to the full sample, the latter two columns are for the sub-sample of managers and professionals. The $\mathrm{F}$ test of the joint significance of the additional instruments is reported at the end of the table. Since the value of the test is always above the rule of thumb value of 10, suggested by Stagier and Stock, 1997, we clearly reject the hypothesis that the selected instruments are weak. As expected, a reduction in the lowest marginal tax rate reduces individual marginal and average taxes. A similar effect is obtained by a reduction in relative taxbands.

[Table 2 about here]

Table 3 shows the Tobit estimates of model (16). As in Table 2, we report the estimates for the full sample and for the sub-sample of managers and professionals. While the first and third column in the table treats the tax variables as exogenous, the second and fourth columns report the estimates of augmented specifications, which include the first step residuals. Since these residuals are jointly signific ant, we cannot reject the hypothesis that the 
tax variables are endogenous. Moreover, we compute the standard errors by bootstrapping, using 200 replications. Our results show that an increase in marginal and average tax rates reduce the relative share of PRP in total pay, consistently with the predictions of the tax augmented principal - agent model. We compute the implied elasticities by evaluating the relevant variables at their sample means ${ }^{13}$. It tums out that a 10 percent reduction in the marginal and average tax rates is expected to increase the relative share of PRP on total pay by 2.80 and 7.99 percent respectively. Since the piece rate $b$ depends in our model only on the marginal tax rate, our estimates also imply that a 10 percent reduction in the average tax rate decreases total pay by 7.99 . These effects are sizeable, and are similar to the estimated effects in the sub-sample of managers, professionals and white collars (-3.50 and -8.15 respectively).

[Table 3 about here]

We investigate the robustness of our results in two directions: first, we use a dynamic specification of the baseline model. Second, we replace the macroeconomic variables with unrestricted time dummies. On the one hand, adding some dynamics may help reduce the problems associated to the dynamic incompleteness of the empirical model specified in (16), as suggested by Wooldridge, 2002. On the other hand, one may question whether a quadratic trend plus the aggregate unemployment rate are sufficient to capture the key macroeconomic effects on the share of PRP. By using unrestric ted time dummies, we capture all macro effects, at the price that we cannot use any longer the instruments TR1 and GAP2, which are aggregate variables. Still, we can use the interactions of these instruments with the gender dummy.

Table 4 reports the estimates of the dynamic model, and Table 5 the estimates where time dummies replace the macroeconomic variables. Starting with the former, we compute the long - run elasticities of the share of PRP to changes in the marginal and average tax rates, and find that, in the full sample, these are equal to -4.19 and -4.58 respectively.

\section{[Table 4 about here]}

\footnotetext{
13 The elasticity of $\mathrm{R}$ to the average tax rate is

$\frac{\partial \ln R}{\partial \ln z}=-\frac{z}{R} \frac{1+R}{1-z} \gamma_{3} \Phi\left(\frac{x^{\prime} \beta}{\sigma}\right)$

where $\sigma$ is the estimated variance of the error tem, computed as in Wooldridge, 2002, p.532.
} 
Tuming to the specification with time dummies, we confirm the qualitative results obtained in Table 3. In this case for the full sample, the estimated elasticities are -0.297 for the marginal tax rate and -0.806 for the average tax rate. We conclude that our key findings are robust to the selected perturbations in the baseline specification.

[Table 5 about here]

The effect of changes in income taxes on the composition of pay is quite substantial. On the one hand, a pure increase in tax progressivity (e.g. a higher marginal tax rate holding constant the average tax rate) reduces the relative importance of PRP. On the other hand, an increase in the proportionality of the tax system (e.g. a higher average tax rate for fixed progressivity) affects negatively the ratio between PRP and total pay. Our empiric al evidence for the UK suggests that tax reforms, which decrease either the progressivity or the proportiona lity of the tax system by changing the tax rates or the tax bands, are likely to have a positive effect on the composition of pay. 


\section{Conclusions}

In this paper, we have extended the standard principal-agent model to incorporate the effects of the tax structure, which we characterize with the average and the marginal tax rate. Following the suggestion by Garen, 1994, that principal - agent theory is diffic ult to test empinically because it relies on a number of unobservables, we have used the strategy of verifying whether our data support the comparative static s of our model. The key result is that the ratio of PRP to total pay should decline when the average tax rate increases.

We have carried out an empirical investigation based on seven waves of the British Household Panel Survey, which includes a specific question on the availability and the amount of performance related pay. Our evidence clearly supports the predictions of the tax augmented principal - agent theory, in that we find that an increase in the average tax rate reduces the relative share of PRP. We also find that PRP is reduced by an increase in the marginal tax rate, conditional on a given average tax rate.

The estimated empirical elasticities a re sizeable, and suggest that a tax reform which reduces average tax rates by 10 percent is likely to lead, as a side effect, to a significant increase in the relative importance of PRP. Interpreted in the light of the current decline in average personal taxation and increase in the use of flexible compensation packages in many OECD countries, our findings offer an interpretation of these two trends which emphasize how tax refoms which reduce the burden of taxes can induce agents to optimally select more flexible forms of compensation. 


\section{Appendix}

\section{Proof of the Result}

The differentiation of $R$ with respect to $z$, given $\tau$, yields

$$
\frac{\partial R}{\partial t}=-\frac{2 \theta^{2}\left[\frac{v \theta^{2}}{1-\tau}+\frac{v \phi \phi r \sigma_{e}^{2}}{(1-z)(1-\tau)^{2}}\right]}{\left[v \theta^{2}+\frac{\phi \varphi r \sigma_{e}^{2}}{(1-\tau)^{2}}+\frac{2 \phi(1+\beta) \rho}{b^{2}(1-\tau)}\right]^{2}}<0
$$

The differentiation of $R$ with respect to $\tau$ yields instead

$$
\frac{\partial R}{\partial \tau}=-\frac{2 \theta^{2}\left[-\frac{\theta^{2}}{1-t}+\frac{\phi r \sigma_{e}^{2}}{(1-t)(1-\tau)^{2}}+\frac{2 \phi(1+\beta) \rho}{b(1-\tau)^{2}}\left(\frac{1}{b}+\frac{1}{2 \frac{\partial b}{\partial \tau}}\right)\right]}{\left[v \theta^{2}+\frac{\phi \nu r \sigma_{e}^{2}}{(1-\tau)^{2}}+\frac{2 \phi(1+\beta) \rho}{b^{2}(1-\tau)}\right]^{2}}
$$

where $\left|\frac{\partial b}{\partial \tau}\right|$ is the absolute value of $\frac{\partial b}{\partial \tau}$. The sign of the above expression is uncertain.

\section{From gross to net monthly eamings in the BHPS}

The calculation of net usual monthly pay relies on J a rvis and Jenkins, 1995, Ba rdasi, J enkins and Rigg, 1999, and Bardasi and Jenkins, 2004. Starting from the most recent usual gross payment received ${ }^{14}$, we consider only employees and compute total gross monthly eamings by adding pay from any eventual second job. From total gross eamings, we calculate taxable eamings by subtracting pension scheme contributions, personal allowances and the Performance Related Pay tax relief when eligible. Following Bardasi and Jenkins, 2004, pension contributions are imputed as $4,7 \%$ of gross eamings for all waves. Personal allowances are imputed using the first two columns of Table A1. Until 2000, tax relieves were given to employees in the private sector with a positive National Insurance contribution, who

\footnotetext{
${ }^{14}$ The variable PAYGU mea sures the usual monthly wage or sa lary payment before tax and other deductions in current main job
} 
were in a Profit Related Pay (PRP) scheme. The amount of PRP which qualified for tax relief was subject to two statutory limits. The first ceiling corresponded to the $20 \%$ of the employee's pay. The second limit was a monetary one. The yearly amount was $f 4000$ in 1997 . The ceiling on relief was reduced to $f 2000$ in 1998 and to $f 1000$ in 1999 . No relief was available since 2000 onward.

Tab A1: Personal Allowancesand National Insurance contributions.

\begin{tabular}{|c|c|c|c|c|c|c|c|c|}
\hline \multirow[b]{3}{*}{ Year } & \multirow{2}{*}{\multicolumn{2}{|c|}{$\begin{array}{c}\text { Non aged } \\
\text { allowances (1) }\end{array}$}} & \multicolumn{6}{|c|}{ National Insurance contributions } \\
\hline & & & \multirow[b]{2}{*}{$\begin{array}{l}\text { Lower } \\
\text { Eamings } \\
\text { limit (1) }\end{array}$} & \multirow[b]{2}{*}{$\begin{array}{l}\text { Upper } \\
\text { Eamings } \\
\text { Limit (1) }\end{array}$} & \multicolumn{3}{|c|}{ Employee contracted in } & \multirow[b]{2}{*}{$\begin{array}{c}\text { Contracteo } \\
\text { out rate }\end{array}$} \\
\hline & Personal & $\begin{array}{l}\text { Mamied- } \\
\text { couple }\end{array}$ & & & $\begin{array}{l}\text { Rate } \\
\text { at LEL }\end{array}$ & $\begin{array}{l}\text { Main } \\
\text { rate }\end{array}$ & $\begin{array}{c}\text { Rate } \\
\text { above } \\
\text { UEL }\end{array}$ & \\
\hline 1997 & 337.8 & 152.5 & 268.66 & 2015 & $2 \%$ & $10 \%$ & $0 \%$ & $8,4 \%$ \\
\hline 1998 & 349.6 & 158.3 & 277.33 & 2101.67 & $2 \%$ & $10 \%$ & $0 \%$ & $8.4 \%$ \\
\hline 1999 & 361.3 & 164.2 & 286 & 2166.67 & $0 \%$ & $10 \%$ & $0 \%$ & $8.4 \%$ \\
\hline 2000 & 365.4 & - & 290.33 & 2318.33 & $0 \%$ & $10 \%$ & $0 \%$ & $8.4 \%$ \\
\hline 2001 & 377.9 & - & 312 & 2491.66 & $0 \%$ & $10 \%$ & $0 \%$ & $8.4 \%$ \\
\hline 2002 & 384.6 & - & 325 & 2535 & $0 \%$ & $10 \%$ & $0 \%$ & $8.4 \%$ \\
\hline 2003 & 384.6 & - & 333.66 & 2578.33 & $0 \%$ & $11 \%$ & $1 \%$ & $9.4 \%$ \\
\hline
\end{tabular}

(1) in $f$ per month. (1)aged-allowancesare not considered because our sample is restric ted to individua ls below 65. Source: www.hmr.gov.ukJ

Taxable eamings are then employed to compute the individual marginal tax rate and gross tax, using the bands and the rates reported in Table A2. We then compute individual tax credits according to the eligibility criteria.

Table A2: Rate of income tax (1)

\begin{tabular}{ccccccc}
\hline \multirow{2}{*}{ Year } & \multicolumn{2}{c}{ Starting rate } & \multicolumn{2}{c}{ Basic rate } & \multicolumn{2}{c}{ Higher rate } \\
\cline { 2 - 7 } & $\begin{array}{c}\text { taxable } \\
\text { bands }\end{array}$ & $\begin{array}{c}\text { rate of } \\
\text { tax } \%\end{array}$ & $\begin{array}{c}\text { taxable } \\
\text { bands }\end{array}$ & $\begin{array}{c}\text { rate of } \\
\text { tax } \%\end{array}$ & $\begin{array}{c}\text { taxable } \\
\text { bands }\end{array}$ & $\begin{array}{c}\text { rate of } \\
\text { tax } \%\end{array}$ \\
\hline 1997 & $1-4,100$ & 20 & $4,101-26,100$ & 23 & Over 26,100 & 40 \\
1998 & $1-4,300$ & 20 & $4,301-27,100$ & 23 & Over 27,100 & 40 \\
1999 & $1-1,500$ & 10 & $1,501-28,000$ & 23 & Over 28,000 & 40 \\
2000 & $1-1,520$ & 10 & $1,521-28,400$ & 22 & Over 28400 & 40 \\
2001 & $1-1,880$ & 10 & $1,881-29,400$ & 22 & Over 29,400 & 40 \\
2002 & $1-1,920$ & 10 & $1,921-29,900$ & 22 & Over 29,900 & 40 \\
2003 & $1-1,960$ & 10 & $1,961-30,500$ & 22 & Over 30,500 & 40 \\
\hline
\end{tabular}

(1) taxable bands refer to annual income. Source: www.hmrc.gov.uk/

Credit a mounts and thresholdscan be found in Table A3. The taxcredits were deducted from the gross tax to compute the net tax. National insurance contributions were imputed to workers according to Table A1. We finally derived the usual net monthly labour income by 
subtracting from gross eamings the estimated income net tax, National Insurance contributions, pension contributions and PRP tax relief when eligible.

Table A3: Monthly tax credits.

\begin{tabular}{|c|c|c|c|c|c|c|c|c|c|}
\hline \multirow[b]{2}{*}{ year } & \multirow[b]{2}{*}{$\begin{array}{c}\text { Maried } \\
\text { couple } \\
\text { allowances }\end{array}$} & \multirow[b]{2}{*}{ WFTC } & \multirow[b]{2}{*}{$\begin{array}{l}30 \\
\text { hours } \\
\text { credit }\end{array}$} & \multicolumn{3}{|c|}{ Child credits } & \multicolumn{2}{|c|}{$\begin{array}{l}\text { Childcare tax } \\
\text { credit (1) }\end{array}$} & \multirow{2}{*}{$\begin{array}{l}\text { Income } \\
\text { threshold } \\
\text {-lone } \\
\text { parent or } \\
\text { couple } \\
\text { (3) }\end{array}$} \\
\hline & & & & underl1 & $11-16$ & $16-18$ & 1 child & $\begin{array}{c}2+ \\
\text { children }\end{array}$ & \\
\hline 1997 & 152,5 & - & - & - & - & - & - & - & - \\
\hline 1998 & 158,3 & - & 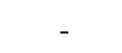 & - & - & - & - & - & - \\
\hline 1999 & 164,16 & & & & & & & & \\
\hline 2000 & & 226.6 & 47.9 & 89.0 & 90.57 & 112.45 & 450 & 675 & 390 \\
\hline 2001 & - & 230.3 & 48.7 & 110.9 & 110.9 & 114.2 & 450 & 675 & 396.3 \\
\hline 2002 & - & 255.7 & 49.6 & 112.7 & 112.7 & 115.9 & 607,5 & 900 & 402.6 \\
\hline 2003 & - & 270.8 & 50.5 & 114.7 & 114.7 & 117.9 & 607.5 & 900 & 409.5 \\
\hline
\end{tabular}

(1) in $f$ per month. (2) The percentage of a llowed childcare costs in credit is $70 \%$. (3) with a taper rate of $55 \%$ and a minimum award per month of $£ 2.17$. Source: www.hmre.gov.ukJ 


\section{References}

- Altonji, J. and Shakotko, R., 1987, Do wages rise with seniority?, The Review of Economic Studies, 54, 437-459

- Bardasi, E., J enkins, S.P., and Rigg, J .A. (1999), ‘Doc umentation for derived current and annual net household income variables, BHPS Waves 1-7', Working Paper 99-25, Institute for Social and Economic Research, University of Essex.

- Bardasi E. and Jenkins S. P, (J une 2004) 'British Household Panel Survey; Derived Current and Annual Net Household Income Variables, Waves 1-12, 1991-2003'. Colchester: University of Essex.

- Booth and Frank, 1999, Eamings, Productivity and Performance Related Pay, The J oumal of Labor Ec onomics, 17, 3, 447-463

- Brewer, Mike; Clark, Tom and Goodman, Alissa. "What Really Happened to Child Poverty in the UK under Labour's First Term?" Economic Joumal, J une 2003, 113(488), F240-F257.

- Conyon, M., and Freeman, R., 2001, Shared modes of compensation and fim performance: UK Evidence, NBER Working Paper 8448.

- Doucouliagos, C., 1995, Worker Participation and Productivity in Labor Managed and Partic ipa tory Capita list Firms: a Meta-Ana lysis, Industrial and Labor Relations Review.

- Francesc oni and van der Klaauw (2004) "Consequences of “In-work” benefit reform in Brita in: Nwe Evidence From Panel Data" IZA Disc ussion paper No 1248

- Garen, J., 1994, Executive compensation and Principal Agent Theory, Joumal of Politic al Economy, 102, 1175-1199

- J a vis, S. and J enkins, S.P. (1997), 'Low income dynamics in 1990s Britain', Fiscal Studies Vol. 18, No. 2, 1-20. Reprinted in IDS Bulletin, 29(1) J a nuary 1998, 32-41.

- Lazear, E., 1999, Personnel Economics: Past lessons and future directions, Joumal of Labor Economics, 17, 199-236

- Lockwood B., Manning A., 1993. Wage setting and the tax system, Joumal of Public Economics, 52, 1-29.

- Lydon and Walker (2004) "Welfare-to-work wages and wage growth" IZA Disc ussion Paper No1144.

- Malcomson J., Sartor N., 1987. Tax push inflation in a unionised labor market, European Economic Review, 31, 1581-1596. 
- Milgrom, P. and Robers, J., 1992, Economics, Organization and Management, Prentice Hall, New York.

- OECD, 1995, Employment Outlook, Paris

- Prendergast, C., 1999, The Provision of Incentives in Fims, Joumal of Economic Literature, 7-63.

- Smith and Blundell, 1986, An exogeneity test for a simulta neous equation tobit model, with an applic ation to la bor supply, Econometric a, 54, 3, 679-685.

- Staiger, D. and Stock J., [1997], Instrumental Variable Regression With Weak Instruments, Econometrica, , 65, 5, pp.557-586.

- Wooldridge, J., 2002, Ec onometric Analysis of Cross Section and Panel Data, The MIT Press, Cambridge, MA. 
Table 1. Summary Statistic s, 1997 and 2003

\begin{tabular}{|c|c|c|c|c|}
\hline \multirow[b]{2}{*}{ Variables } & \multicolumn{2}{|c|}{1997} & \multicolumn{2}{|c|}{2003} \\
\hline & All sample & $\begin{array}{c}\text { Manager } \\
\text { and } \\
\text { Professionals }\end{array}$ & All sample & $\begin{array}{c}\text { Manager } \\
\text { and } \\
\text { Professionals }\end{array}$ \\
\hline Age & 36.7 & 36.7 & 37.9 & 37.2 \\
\hline Ma ried & .57 & .57 & .55 & .56 \\
\hline Gender $($ male $=1)$ & .56 & .51 & .56 & .52 \\
\hline Part-time & .16 & .12 & .16 & .13 \\
\hline Union in the workplace & .18 & .15 & .18 & .15 \\
\hline Unemployed father & .06 & .05 & .07 & .05 \\
\hline Voted for Labour & .35 & .30 & .25 & .30 \\
\hline Windfa ll gains & .22 & .22 & .10 & .12 \\
\hline Lack of sleep & .64 & .66 & .66 & .67 \\
\hline White & .96 & .96 & .93 & .95 \\
\hline Pemanent job & .94 & .95 & .97 & .96 \\
\hline Smoker & .32 & .25 & .31 & .25 \\
\hline Average tax rate & .11 & .13 & .12 & .14 \\
\hline Marginal tax rate & .231 & .24 & .223 & .24 \\
\hline Net usual monthly ea mings (1) & 997.5 & 1176.25 & 1222.5 & .1346 \\
\hline G ross usual monthly ea mings (1) & 1395.2 & 1688.2 & 1616.2 & .1827 \\
\hline$\%$ with PRP & .361 & .44 & .335 & .43 \\
\hline Monthly net PRP (if positive) (1) & 119 & 159.2 & 165.13 & 184.0 \\
\hline Share of PRP on total pay, if $P R P>0$ & .066 & .074 & .064 & .076 \\
\hline $\begin{array}{l}\text { Number of ind ividual-wave } \\
\text { observations }\end{array}$ & 3322 & 1672 & 4301 & 1884 \\
\hline
\end{tabular}

(1) in 2005 prices 
Table 2. First stage regressions. Full sample and sub-sample of managers, professionals and white collars.

\begin{tabular}{|c|c|c|c|c|}
\hline & $\ln (1-\tau)$ & $\ln (1-z)$ & $\ln (1-\tau)$ & $\ln (1-z)$ \\
\hline age & $\begin{array}{l}-0.000 \\
{[2.85]^{* * *}}\end{array}$ & $\begin{array}{l}-0.001 \\
{[6.07]^{* * *}}\end{array}$ & $\begin{array}{l}-0.001 \\
{[2.13]^{* *}}\end{array}$ & $\begin{array}{l}-0.001 \\
{[5.49]^{*} * *}\end{array}$ \\
\hline age2 & $\begin{array}{l}0.000 \\
{[2.89]^{* 1 * *}}\end{array}$ & $\begin{array}{l}0.000 \\
{[5.46]^{* * 4 k}}\end{array}$ & $\begin{array}{l}0.000 \\
{[1.86]^{*}}\end{array}$ & $\begin{array}{l}0.000 \\
{[4.92]^{\text {*ak }}}\end{array}$ \\
\hline maried & $\begin{array}{l}-0.001 \\
{[1.11]}\end{array}$ & $\begin{array}{l}0.000 \\
{[0.04]}\end{array}$ & $\begin{array}{l}-0.001 \\
{[0.62]}\end{array}$ & $\begin{array}{l}0.000 \\
{[0.49]}\end{array}$ \\
\hline gender $($ male $=1)$ & $\begin{array}{l}0.032 \\
{[1.10]}\end{array}$ & $\begin{array}{l}-0.05 \\
{[2.81]^{* * *}}\end{array}$ & $\begin{array}{l}-0.171 \\
{[3.74]^{* * *}}\end{array}$ & $\begin{array}{l}-0.119 \\
{[4.94]^{* * 1 *}}\end{array}$ \\
\hline part time & $\begin{array}{l}0.011 \\
{[13.23]^{* * * *}}\end{array}$ & $\begin{array}{l}0.01 \\
{[18.00]^{* * * *}}\end{array}$ & $\begin{array}{l}0.008 \\
{[5.85]^{* 4 * *}}\end{array}$ & $\begin{array}{l}0.01 \\
{[10.53]^{* * *}}\end{array}$ \\
\hline union in the workplace & $\begin{array}{l}0.001 \\
{[1.14]}\end{array}$ & $\begin{array}{l}0.000 \\
{[0.65]}\end{array}$ & $\begin{array}{l}0.001 \\
{[1.23]}\end{array}$ & $\begin{array}{l}0.000 \\
{[0.80]}\end{array}$ \\
\hline unemployed father & $\begin{array}{l}-0.000 \\
{[0.39]}\end{array}$ & $\begin{array}{l}-0.000 \\
{[0.59]}\end{array}$ & $\begin{array}{l}-0.000 \\
{[0.01]}\end{array}$ & $\begin{array}{l}0.000 \\
{[0.37]}\end{array}$ \\
\hline voted forlabor & $\begin{array}{l}-0.001 \\
{[1.42]}\end{array}$ & $\begin{array}{l}-0.000 \\
{[1.29]}\end{array}$ & $\begin{array}{l}-0.000 \\
{[0.15]}\end{array}$ & $\begin{array}{l}-0.000 \\
{[0.33]}\end{array}$ \\
\hline wind fall gains & $\begin{array}{l}0.000 \\
{[0.11]}\end{array}$ & $\begin{array}{l}-0.000 \\
{[0.07]}\end{array}$ & $\begin{array}{l}-0.001 \\
{[0.49]}\end{array}$ & $\begin{array}{l}0.001 \\
{[1.17]}\end{array}$ \\
\hline lack of sleep & $\begin{array}{l}-0.000 \\
{[0.45]}\end{array}$ & $\begin{array}{l}-0.000 \\
{[0.07]}\end{array}$ & $\begin{array}{l}0.001 \\
{[0.64]}\end{array}$ & $\begin{array}{l}-0.000 \\
{[0.87]}\end{array}$ \\
\hline white & $\begin{array}{l}-0.002 \\
{[1.13]}\end{array}$ & $\begin{array}{l}-0.001 \\
{[1.42]}\end{array}$ & $\begin{array}{l}-0.002 \\
{[0.80]}\end{array}$ & $\begin{array}{l}-0.000 \\
{[0.37]}\end{array}$ \\
\hline permanent job & $\begin{array}{l}0.002 \\
{[1.45]}\end{array}$ & $\begin{array}{l}-0.001 \\
{[1.37]}\end{array}$ & $\begin{array}{l}0.001 \\
{[0.47]}\end{array}$ & $\begin{array}{l}-0.001 \\
{[0.52]}\end{array}$ \\
\hline smoker & $\begin{array}{l}-0.000 \\
{[0.17]}\end{array}$ & $\begin{array}{l}-0.000 \\
{[0.47]}\end{array}$ & $\begin{array}{l}-0.001 \\
{[1.11]}\end{array}$ & $\begin{array}{l}-0.000 \\
{[0.73]}\end{array}$ \\
\hline unemployment rate & $\begin{array}{l}-1.545 \\
{[2.81]^{\text {*atk }}}\end{array}$ & $\begin{array}{l}-2.694 \\
{[7.68]^{* * * *}}\end{array}$ & $\begin{array}{l}-1.718 \\
{[1.91]^{*}}\end{array}$ & $\begin{array}{l}-2.559 \\
{[5.12]^{* * *}}\end{array}$ \\
\hline dummy=1 if yea $>1999$ & $\begin{array}{l}-0.005 \\
{[1.26]}\end{array}$ & $\begin{array}{l}-0.015 \\
{[6.14]^{* * *}}\end{array}$ & $\begin{array}{l}-0.001 \\
{[0.24]}\end{array}$ & $\begin{array}{l}-0.012 \\
{[3.59]^{*} \text { *ak }}\end{array}$ \\
\hline marginal tax rate tr 1 & $\begin{array}{l}-1.956 \\
{[2.38]^{* *}}\end{array}$ & $\begin{array}{l}-3.517 \\
{[6.68]^{* * *}}\end{array}$ & $\begin{array}{l}-2.197 \\
{[1.61]}\end{array}$ & $\begin{array}{l}-3.255 \\
{[4.27]^{* * *}}\end{array}$ \\
\hline gap2 & $\begin{array}{l}-0.078 \\
{[2.36]^{* *}}\end{array}$ & $\begin{array}{l}-0.14 \\
{[6.63]^{* * *}}\end{array}$ & $\begin{array}{l}-0.088 \\
{[1.60]}\end{array}$ & $\begin{array}{l}-0.129 \\
{[4.24]^{* 4 *}}\end{array}$ \\
\hline female *tr1 & $\begin{array}{l}-0.21 \\
{[12.92]^{* * *}}\end{array}$ & $\begin{array}{l}-0.043 \\
{[4.13]^{* 1 * k}}\end{array}$ & $\begin{array}{l}-0.117 \\
{[4.62]^{* 4 * k}}\end{array}$ & $\begin{array}{l}-0.034 \\
{[2.39]^{* *}}\end{array}$ \\
\hline male $*$ tr2 & $\begin{array}{l}-0.243 \\
{[1.79]^{*}}\end{array}$ & $\begin{array}{l}0.216 \\
{[2.62]^{* * *}}\end{array}$ & $\begin{array}{l}0.707 \\
{[3.32]^{* * * *}}\end{array}$ & $\begin{array}{l}0.53 \\
{[4.71]^{* * *}}\end{array}$ \\
\hline $\begin{array}{l}\text { Observations } \\
\text { F test for the inclusion of }\end{array}$ & 29731 & 29731 & 13864 & 13864 \\
\hline instruments & 74.26 & 29.62 & 25.68 & 22.94 \\
\hline
\end{tabular}

Note: each regression includes a constant, education, fim size, industry, regional and oc cupational dummies; controls for the previous job, a linear and a quadratic trend. Robust standard errors. T-statistic s within brackets. 
Table 3. Tobit estimates, treating tax variables as exogenous and endogenous. Full sample and sub-sample of managers, professionals and white collars. Dependent variable: $\log (1+R)$

\begin{tabular}{|c|c|c|c|c|}
\hline & [1] & [2] & [3] & [4] \\
\hline \multirow[t]{2}{*}{ age } & 0.003 & 0.002 & 0.005 & 0.004 \\
\hline & {$[5.96]^{* 1 *}$} & {$[4.58]^{* * *}$} & {$[6.22]^{* 1 *}$} & {$[4.45]^{* * *}$} \\
\hline \multirow[t]{2}{*}{ age2 } & -0.000 & -0.000 & -0.000 & -0.000 \\
\hline & {$[7.49]^{* * *}$} & {$[6.19]^{* * *}$} & {$[7.29]^{* 1 *}$} & {$[5.70]^{* * *}$} \\
\hline \multirow{2}{*}{ maried } & 0.011 & 0.01 & 0.015 & 0.013 \\
\hline & {$[6.89]^{* * *}$} & {$[6.54]^{* * *}$} & {$[6.40]^{* 1 *}$} & {$[5.37]^{* * *}$} \\
\hline \multirow[t]{2}{*}{ gender $($ male $=1)$} & 0.011 & 0.005 & 0.006 & 0.001 \\
\hline & {$[6.76]^{* 1 *}$} & {$[2.47]^{* *}$} & {$[2.79]^{* 1 *}$} & {$[0.33]$} \\
\hline \multirow[t]{2}{*}{ part time } & -0.021 & -0.013 & -0.016 & -0.011 \\
\hline & {$[9.33]^{* * *}$} & {$[5.49]^{* * *}$} & {$[4.78]^{* 1 *}$} & {$[2.83]^{* * *}$} \\
\hline \multirow{2}{*}{ union in the workplace } & 0.01 & 0.01 & 0.017 & 0.018 \\
\hline & {$[5.58]^{* 1 *}$} & {$[6.19]^{* * *}$} & {$[6.28]^{* 1 *}$} & {$[7.62]^{* * *}$} \\
\hline \multirow[t]{2}{*}{ unemployed father } & -0.006 & -0.006 & 0.003 & 0.004 \\
\hline & {$[2.37]^{* *}$} & {$[2.13]^{* *}$} & {$[0.68]$} & {$[0.96]$} \\
\hline \multirow{2}{*}{ voted Labour } & -0.002 & -0.001 & 0.000 & 0.001 \\
\hline & [1.01] & {$[0.41]$} & {$[0.09]$} & {$[0.48]$} \\
\hline \multirow[t]{2}{*}{ windfall gain } & 0.008 & 0.009 & 0.007 & 0.008 \\
\hline & {$[4.43]^{* * *}$} & {$[4.93]^{* * *}$} & {$[2.78]^{* 1 *}$} & {$[3.18]^{* * *}$} \\
\hline \multirow[t]{2}{*}{ lack of sleep } & -0.003 & -0.003 & -0.005 & -0.005 \\
\hline & [2.06] $]^{* *}$ & [1.91]* & {$[2.33]^{* *}$} & {$[2.33]^{* *}$} \\
\hline \multirow[t]{2}{*}{ white } & 0.011 & 0.012 & 0.003 & 0.004 \\
\hline & {$[2.98]^{* * *}$} & {$[3.07]^{* * *}$} & {$[0.55]$} & {$[0.78]$} \\
\hline permanent job & $\begin{array}{l}0.047 \\
{[10.29]^{* * *}}\end{array}$ & $\begin{array}{l}0.045 \\
{[9.02]^{*+k}}\end{array}$ & $\begin{array}{l}0.06 \\
{[8.64]^{\text {*akk }}}\end{array}$ & $\begin{array}{l}0.057 \\
{[7.16]^{* 1 * k}}\end{array}$ \\
\hline \multirow[t]{2}{*}{ smoker } & -0.008 & -0.007 & -0.01 & -0.009 \\
\hline & {$[5.42]^{* * *}$} & {$[5.20]^{* * *}$} & {$[4.36]^{* * *}$} & {$[3.66]^{* * *}$} \\
\hline \multirow[t]{2}{*}{$\ln (1-\tau)^{\wedge}$} & -0.085 & 0.065 & -0.091 & 0.082 \\
\hline & {$[4.83]^{* 1 *}$} & {$[2.84]^{* * *}$} & {$[3.95]^{* 1 *}$} & {$[2.62]^{* * *}$} \\
\hline \multirow[t]{2}{*}{$\ln (1-z)^{\wedge}$} & 0.379 & 0.395 & 0.409 & 0.38 \\
\hline & [12.97] & {$[10.43]^{* * *}$} & {$[9.50]^{* 1 *}$} & {$[6.61]^{* * *}$} \\
\hline \multirow[t]{2}{*}{ first stage residua $\operatorname{ls} \ln (1-\tau)^{\wedge}$} & & -0.153 & & -0.173 \\
\hline & & {$[10.01]^{* * *}$} & & {$[8.60]^{* * *}$} \\
\hline \multirow[t]{2}{*}{ first stage residuals $\ln (1-z)^{\wedge}$} & & -0.049 & & -0.003 \\
\hline & & [1.96]* & & {$[0.07]$} \\
\hline \multirow{2}{*}{ unemployment rate } & -0.06 & -0.123 & 0.013 & -0.047 \\
\hline & [0.15] & {$[0.31]$} & {$[0.02]$} & {$[0.09]$} \\
\hline \multirow[t]{2}{*}{ dummy=1 if year $>1999$} & 0.002 & 0.001 & 0.001 & 0.001 \\
\hline & [0.55] & [0.42] & [0.22] & {$[0.14]$} \\
\hline Observations & 29731 & 29731 & 13864 & 13864 \\
\hline
\end{tabular}

Note: each regression includes a constant, education, firm size, industry, regional and occupational dummies; controls for health, previous job, a linear and a quadratic trend. ^ Deviation of the variable from the individual mean. Robust standard errors in columns (1) and (3). Bootstrapped standard emors in columns (2) and (4). T-statistics within brackets. Three, two and one star for signific ance levels of 1, 5 and 10 percent. 
Table 4. Tobit estimates, treating tax variables as exogenous and endogenous. Full sample a nd subsample of managers and professionals. With lagged variables. Dependent variable: $\log (1+R)$

\begin{tabular}{|c|c|c|c|c|}
\hline & [1] & [2] & [3] & [4] \\
\hline \multirow[t]{2}{*}{ age } & 0.001 & 0.000 & 0.001 & 0.000 \\
\hline & -1.65 & -0.37 & -1.85 & -0.58 \\
\hline \multirow[t]{2}{*}{ age2 } & 0.000 & 0.000 & 0.000 & 0.000 \\
\hline & $(2.96)^{* *}$ & -1.9 & $(2.78)^{* *}$ & -1.61 \\
\hline \multirow[t]{2}{*}{ maried } & 0.005 & 0.005 & 0.007 & 0.006 \\
\hline & $(3.45)^{* *}$ & $(3.37) * *$ & $(3.04)^{* *}$ & $(2.50)^{*}$ \\
\hline \multirow{2}{*}{ gender (male $=1$ ) } & 0.006 & 0.000 & 0.002 & -0.003 \\
\hline & $(3.50) * *$ & -0.2 & -0.85 & -1.28 \\
\hline \multirow[t]{2}{*}{ part time } & -0.012 & -0.004 & -0.008 & -0.002 \\
\hline & $(5.15)^{* *}$ & -1.7 & $(2.43) *$ & -0.53 \\
\hline \multirow[t]{2}{*}{ union in the workplace } & 0.006 & 0.006 & 0.011 & 0.012 \\
\hline & $(3.63)^{* *}$ & $(3.85) * *$ & $(4.09) * *$ & $(4.60)^{* *}$ \\
\hline \multirow[t]{2}{*}{ unemployed father } & -0.003 & -0.003 & 0.004 & 0.004 \\
\hline & -1.25 & -1.21 & -0.88 & -0.95 \\
\hline \multirow[t]{2}{*}{ voted Labour } & 0.000 & 0.000 & 0.002 & 0.003 \\
\hline & -0.2 & -0.31 & -1.12 & -1.56 \\
\hline \multirow[t]{2}{*}{ windfall gain } & 0.007 & 0.007 & 0.007 & 0.008 \\
\hline & $(3.63)^{* *}$ & $(4.20) * *$ & $(2.64)^{* *}$ & $(3.17)^{* *}$ \\
\hline \multirow{2}{*}{ lack of sleep } & -0.003 & -0.002 & -0.004 & -0.003 \\
\hline & -1.86 & -1.81 & -1.8 & -1.66 \\
\hline \multirow[t]{2}{*}{ white } & 0.009 & 0.008 & 0.003 & 0.002 \\
\hline & $(2.20)^{*}$ & $(2.12)^{*}$ & -0.51 & -0.41 \\
\hline \multirow[t]{2}{*}{ permanent job } & 0.036 & 0.034 & 0.044 & 0.041 \\
\hline & $(6.83)^{* *}$ & $(5.55)^{* *}$ & $(5.82) * *$ & $(4.84)^{* *}$ \\
\hline \multirow[t]{2}{*}{ smoker } & -0.007 & -0.006 & -0.009 & -0.007 \\
\hline & $(4.71) * *$ & $(4.47)^{* *}$ & $(3.80) * *$ & $(3.07)^{* *}$ \\
\hline \multirow{2}{*}{$\ln (1-\tau)^{\wedge}$} & -0.019 & 0.051 & -0.03 & 0.064 \\
\hline & -1.09 & $(2.13)^{*}$ & -1.37 & $(2.02)^{*}$ \\
\hline \multirow[t]{2}{*}{$\ln (1-z)^{\wedge}$} & 0.175 & 0.264 & 0.209 & 0.255 \\
\hline & $(5.81)^{* *}$ & $(6.20)^{* *}$ & $(4.76)^{* *}$ & $(3.43)^{* *}$ \\
\hline \multirow[t]{2}{*}{$\ln (1-\tau)^{\wedge}(-1)$} & 0.017 & 0.015 & 0.031 & 0.023 \\
\hline & -1.01 & -0.74 & -1.4 & -0.97 \\
\hline \multirow{2}{*}{$\ln (1-z) \wedge(-1)$} & -0.122 & -0.117 & -0.218 & -0.225 \\
\hline & $(4.32)^{* *}$ & $(4.04)^{* *}$ & $(5.35) * *$ & $(4.44)^{* *}$ \\
\hline \multirow[t]{2}{*}{$\ln (1+R)(-1)$} & 0.744 & 0.729 & 0.75 & 0.735 \\
\hline & $(59.39)^{* *}$ & $(34.65)^{* *}$ & $(46.54)^{* *}$ & $(28.99)^{* *}$ \\
\hline \multirow[t]{2}{*}{ first stage residua $\operatorname{ls} \ln (1-\tau)^{\wedge}$} & & -0.062 & & -0.083 \\
\hline & & $(4.26) * *$ & & $(4.05)^{* *}$ \\
\hline \multirow[t]{2}{*}{ first stage residua Is $\ln (1-z)^{\wedge}$} & & -0.124 & & -0.077 \\
\hline & & $(4.82) * *$ & & -1.83 \\
\hline \multirow[t]{2}{*}{ unemployment rate } & 0.786 & 0.766 & 0.826 & 0.798 \\
\hline & $(1.98) *$ & $(2.01)^{*}$ & -1.48 & -1.48 \\
\hline \multirow[t]{2}{*}{ dummy=1 if yea $>1999$} & 0.004 & 0.004 & 0.006 & 0.006 \\
\hline & -1.02 & -1.18 & -1.15 & -1.18 \\
\hline Observations & 21228 & 21228 & 10338 & 10338 \\
\hline
\end{tabular}

Note: See Table 3 
Table 5. Tobit estimates, treating tax variables as exogenous and endogenous. Full sample and sub-sample of managers, professiona ls and white collars. Dependent variable: log(1+R). With time dummies

\begin{tabular}{|c|c|c|c|c|}
\hline & [1] & [2] & [3] & [4] \\
\hline \multirow[t]{2}{*}{ age } & 0.003 & 0.002 & 0.005 & 0.004 \\
\hline & 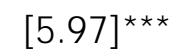 & {$[4.59]^{* * *}$} & {$[6.25]^{* * *}$} & {$[4.51]^{* * *}$} \\
\hline \multirow[t]{2}{*}{ age2 } & 0.000 & 0.000 & 0.000 & 0.000 \\
\hline & {$[7.50]^{* * *}$} & {$[6.20]^{* * *}$} & {$[7.32]^{* * *}$} & {$[5.88]^{* * *}$} \\
\hline \multirow[t]{2}{*}{ married } & 0.011 & 0.01 & 0.015 & 0.013 \\
\hline & {$[6.90]^{* * *}$} & {$[6.54]^{* * *}$} & {$[6.40]^{* * *}$} & {$[4.77]^{* * *}$} \\
\hline \multirow[t]{2}{*}{ gender (male $=1$ ) } & 0.011 & 0.005 & 0.006 & 0.001 \\
\hline & {$[6.77]^{\text {*ak }}$} & {$[2.47]^{* *}$} & {$[2.79]^{\text {*ak }}$} & [0.32] \\
\hline \multirow[t]{2}{*}{ part time } & -0.021 & -0.013 & -0.016 & -0.01 \\
\hline & {$[9.34]^{* 1 *}$} & {$[5.49]^{* * *}$} & {$[4.78]^{\text {*a*k }}$} & {$[2.81]^{* * * *}$} \\
\hline \multirow[t]{2}{*}{ union in the workplace } & 0.01 & 0.01 & 0.017 & 0.018 \\
\hline & {$[5.59]^{* * *}$} & {$[6.20]^{* * *}$} & {$[6.28]^{* * *}$} & {$[8.33]^{* * *}$} \\
\hline \multirow[t]{2}{*}{ unemployed father } & -0.006 & -0.006 & 0.003 & 0.004 \\
\hline & {$[2.37]^{* *}$} & {$[2.13]^{* *}$} & [0.68] & {$[0.88]$} \\
\hline \multirow[t]{2}{*}{ voted Labour } & -0.002 & -0.001 & 0.000 & 0.001 \\
\hline & [1.04] & {$[0.45]$} & [0.02] & [0.45] \\
\hline \multirow[t]{2}{*}{ windfall gain } & 0.008 & 0.009 & 0.007 & 0.008 \\
\hline & {$[4.39]^{* 1 *}$} & {$[4.90]^{* * *}$} & {$[2.70]^{* * *}$} & {$[3.51]^{* * *}$} \\
\hline \multirow[t]{2}{*}{ lack of sleep } & -0.003 & -0.003 & -0.005 & -0.005 \\
\hline & {$[2.06]^{* *}$} & [1.91]* & {$[2.34]^{* *}$} & {$[2.34]^{* *}$} \\
\hline \multirow{2}{*}{ white } & 0.011 & 0.012 & 0.003 & 0.004 \\
\hline & {$[3.03]^{* 1 *}$} & {$[3.11]^{* * *}$} & [0.57] & [0.79] \\
\hline permanent job & $\begin{array}{l}0.047 \\
{[10307 \text { *ak }}\end{array}$ & 0.045 & $\begin{array}{c}0.06 \\
0.097 * 4 *\end{array}$ & $\begin{array}{l}0.057 \\
{[6.81]^{* * *}}\end{array}$ \\
\hline \multirow[t]{2}{*}{ smoker } & $\begin{array}{l}{[10.30]} \\
-0.008\end{array}$ & -0.007 & -0.01 & -0.009 \\
\hline & {$[5.43]^{* * *}$} & {$[5.19]^{* * *}$} & {$[4.38]^{* * *}$} & {$[3.57]^{* * *}$} \\
\hline \multirow[t]{2}{*}{$\ln (1-\tau)^{\wedge}$} & -0.085 & 0.065 & -0.091 & 0.082 \\
\hline & {$[4.83]^{* \alpha *}$} & {$[2.82]^{* * *}$} & {$[3.95]^{* * *}$} & {$[2.43]^{* *}$} \\
\hline \multirow[t]{2}{*}{$\ln (1-z)^{\wedge}$} & 0.381 & 0.398 & 0.414 & $\begin{array}{l}0.386 \\
0.721 * x *\end{array}$ \\
\hline & & $\begin{array}{c}{[10.45]^{* 0.153}} \\
-0.153\end{array}$ & {$[9.61]^{\text {*N* }}$} & $\begin{array}{l}{[6.12]^{\text {Nex }}} \\
-0.173\end{array}$ \\
\hline first sta ge residua $\ln \ln (1-\tau)^{\wedge}$ & & {$[10.00]^{* * * *}$} & & {$[9.49]^{* * *}$} \\
\hline \multirow[t]{2}{*}{ first stage residua Is $\ln (1-z)^{\wedge}$} & & -0.05 & & -0.004 \\
\hline & & {$[1.99]^{* *}$} & & [0.10] \\
\hline Observations & 29731 & 29731 & 13864 & 13864 \\
\hline
\end{tabular}

Note: see Table 3 